\title{
Neuroimaging of AIDS
}

Mardjohan Hardjasudarma ${ }^{1}$ and Marjadi Hardjasudarma ${ }^{2}$

\begin{abstract}
Abstrak
Peningkatan jumlah kasus HIV positif dan AIDS baik di Indonesia maupun di seluruh dunia hampir pasti telah atau akan menyebabkan peningkatan hasil imajing susunan saraf pusat yang positif. Walaupun tidak ada gunanya melakukan skrining rutin dengan computerized tomography (CT) atau magnetic resonance inaging (MRI) pada susunan saraf pusat penderita HIV positif yang tidak bergejala, kedua cara tadi (terutama MRI) sangat baik untuk mendeteksi dan penatalaksanaan kelainan susunan saraf pusat pada penderita yang bergejala. Atrofi otak adalah temuan yang tersering (40\%); kelainan ini biasanya ditemukan pada ensefalitis HIV subakut, kompleks demensia AIDS dan beberapa infeksi oportunis. Massa intrakranial pada AIDS paling sering disebabkan toksoplasmosis dan limfoma, jarang terjadi oleh sarkoma Kaposi, tuberkuloma, abses akibat infeksi jamur dan bakteri. Karena diagnosis dini toksoplasmosis dan pengobatannya yang tepat dapat mengubah perjalanan penyakit tersebut secara bermakna, perlu sekali infeksi parasit itu dibedakan dari limfoma. Hal ini dapat menyulitkan, mengingat kedua penyakit tersebut memiliki banyak ciri imajing yang sama. Seringkali suatu pengobatan antitoksoplasmosis yang dilakukan secara empiris dapat menyelesaikan masalah tersebut. Kelainan masa kelabu otak sering ditemukan pada ensefalitis HIV subakut, kompleks demensia AIDS dan ensefalopati multifokal progresif: pada penyakit terakhir ini dapat terjadi penambahan intensitas gambar (enhancement). Perubahan leptomeni-ngeal dan ependimal jarang ditemukan, tetapi dapat terjadi pada beberapa infeksi oportunis dan neoplasma. CT dapat mendeteksi sebagian besar kelainan yang luas ini, tetapi pada kebanyakan kasus, MRI lebih unggul.
\end{abstract}

\begin{abstract}
The increasing numbers of HIV-positive and AIDS cases, both in Indonesia and worldwide, have caused or will almost certainly be attended by an increase of positive results of imaging studies of the central nervous system (CNS). Whereas it is useless to do routine screening with cranial CT or MRI for asymptomatic HIV positive individuals, imaging modalities and especially MRI are very good in detecting, and monitoring the CNS abnormalities in symptomatic patients. Cerebral atrophy is the most common finding (40\%), and is usually seen in subacute HIV encephalitis, and the AIDS dementia complex (ADC), as well as some of the opportunistic infections. Intracranial masses are most commonly caused by toxoplasmosis and lymphoma, and rarely by Kaposi's sarcoma, tuberculoma, fungal and bacterial abscesses. Since early diagnosis of toxoplasmosis and appropriate therapy can significantly alter the course of the disease, differentiating this parasitic infection from lymphoma is crucial. This can be difficult since both entities share many imaging characteristics. An empirical anti-toxoplasmosis drug therapy trial is often helpful. White matter abnormalities are common in subacute $H I V$ encephalitis, $A D C$ and progressive multifocal leuco encephalopathy' (PML). Leptomeningeal and ependymal changes are rare, but can arise in conjunction with some of the opportunistic infections and neoplasms. CT will detect many of the more extensive abnormalities, but MRI is better in most cases.
\end{abstract}

Keywords : HIV, brain, CT, MRI, infection, immlunocompromised.

\section{INTRODUCTION}

The acquired immune deficiency syndrome (AIDS) is rapidly spreading worldwide, with devastating consequences reaching far beyond the medical effects. Developing countries suffer proprotionally more due to underfunding, insufficient equipment and trained personnel, and often a lack of understanding as to the gravity of the problem. Nevertheless, an increasing number of cases will eventually be exposed to diagnostic imaging. This article will review the imaging characteristics of AIDS of the central nervous system (CNS) within the context of an often confusing and inadequate epidemiologic and clinical picture.

\footnotetext{
${ }_{1}^{1}$ Department of Radiology, Louisiana State University Medical Center, Shreveport, Louisiana, USA

${ }^{2}$ Department of Anatomy, Faculty of Medicine, University of Indonesia, Jakarta, Indonesia
} 


\section{EPIDEMIOLOGY}

The number of human immunodeficiency virus (HIV) positive cases in the United States was 1-2 million, with 3 million worldwide in 1988. This was projected to increase tenfold in 4 years. There were 22,000 AIDS cases in the U.S. in 1986, with 50,000 new cases being reported every year. ${ }^{1,2}$ In 1992 the World Health Organization (W.H.O) reported an excess of 500,000 cases worldwide and felt that the true number was closer to 2 million. $^{3}$ In addition, an estimated 8-10 million adults and 1 million children were HIV-positive. $^{4}$

The first case of AIDS in Indonesia was reported in $1987 .{ }^{4}$ By 1992 , there were 33 AIDS and $111 \mathrm{HIV}$ positive cases. ${ }^{5}$ These figures are believed to be spuriously low, by a factor of 100 or more, due to underdiagnosis and underreporting. ${ }^{6}$ As has been observed in other parts of the world, it is felt that the pattern of transmission will soon also involve women and the heterosexual population in ever increasing numbers. ${ }^{5}$

Following HIV infection, seroconversion takes 2-6 months or more, whereas the incubation period for AIDS is 6 months to 15 years or longer, with a mean and median of approximately 10 years. Ten to $18 \%$ of people who are HIV-positive will develop AIDS in 5 years, by 10 years this grows to $50 \%$. Another $54 \%$ will develop the AIDS related complex (ARC) in 5 years, and of these $25 \%$ will have AIDS in 3 years. There is controversy regarding surveillance criteria developed by the Centers for Disease Control (C.D.C.) for ARC since it can have little prognostic value. In fact, patients can die from ARC without ever developing AIDS.

Forty percent of AIDS/ARC cases will develop abnormalities of the CNS, and another $10 \%$ will present with a CNS lesion as the first sign. At autopsy, $73-80 \%$ show CNS lesions, and $71 \%$ have more than one pathologic abnormality, suggesting that many of the CNS infections remain subclinical.

Although the risk becoming HIV infected is now an occupational hazard, health care workers need to be reminded that the possibility of contracting Hepatitis$B$ from an accidental needle stick is $15-75$ times greater than AIDS. Optimal protection is always mandatory, and the importance of being vaccinated against Hepatitis-B can not be overemphasized. ${ }^{1,2}$

\section{NEUROIMAGING}

Opportunistic infections involve the CNS in $20-40 \%$ of AIDS cases, and tumors in 5-15\%. The so-called "HIV-related" category affects $30-60 \%$, of which the AIDS dementia complex (ADC) is the most prominent.
Cerebrovascular accidents (CVA) are reported in 3$10 \%{ }^{1}$

\section{Infections}

Toxoplasmosis, cryptococcal meningitis, progressive multifocal leukoencephalopathy (PML), cytomegalovirus (CMV), cysticercosis, amebic meningitis, nocardia, E.coli, T.pallidum, and others.

\section{Toxoplasmosis}

In the adult AIDS patient, Toxoplasma gondii can cause a fulminant necrotizing encephalitis. It is the most frequent opportunistic brain infection, and the most common cause of an intracranial mass in AIDS. ${ }^{1,7}$ Toxoplasma lesions are most commonly located in the basal ganglia and at the gray-white matter junction of the cerebrum. Cerebellar and brain stem lesions are much less common. Magnetic resonance imaging (MRI) is more sensitive in detecting old and new toxoplasma lesions. On long TR/TE images the lesions, which are often multiple, are of variable signal intensity, and can usually be identified as nodular foci surrounded by edema. Enhancement patterns are usually ring-like, although small lesions can appear solid, on both computed tomography (CT) and MRI. From the clinical standpoint, the most important pathologic entity which may have a similar appearance in lymphoma, especially if there is just a single lesion. When toxoplasma encephalitis is suspected based on clinical and imaging data, empirical treatment is initiated. If effective, follow-up imaging studies will document a decrease in the degree of edema and enhancement of the lesions in 2-4 weeks. If not, other causes, especially lymphoma should be considered. In certain cases, stereotactic brain biopsy may be indicated. Old or healed toxoplasma lesions can mineralize. CT is usually better to detect these calcifications, than MRI. ${ }^{7}$

\section{$P M L$}

At least $1-4 \%$ of AIDS patients are found to have PML. This infection, rare in the non-immunocompromised host, is caused by group B human papovaviruses, and primarily the $\mathrm{JC}$ virus. It mainly causes demyelination, and long TR/TE spin-echo MRI is thus much more sensitive than $\mathrm{CT}$, typically showing hyperintense lesions in the centrum semiovale. The lesions are limited to the infratentorial compartment in $10 \%$ of cases. In non-AIDS patients, gray matter involvement is uncommon, there is no mass effect and no enhancement. In AIDS, gray matter can be involved in up to 
$50 \%$ of cases, there can be extension across the corpus callosum, mass effect, and enhancement. ${ }^{8}$ Even the white matter lesions tend to be more variable in appearance. In one series, all lesions were asymmetrical. ${ }^{1,7,9}$

\section{Cryptococcosis}

On MRI, punctate hyperintensities are found, representing cryptococcomas or Virchow-Robin spaces dilated by the infectious organism. Contrast enhancement is uncommon, and although MRI is more sensitive than CT, both modalities underestimate the pathologic extent of the disease. ${ }^{10}$

\section{$C M V$}

This organism is often asymptomatic, and seldom demonstrable on either CT or MRI. CT may show enhancing subependymal lesions. MRI has been reported to show periventricular hyperintensity. CMV is also the most common causative organism in retinal infections in AIDS. 1,7

\section{Herpes}

Both HSV-I and HSV-II can cause encephalitis in AIDS patients. There is a predilection for the temporal lobes, which are usually unilaterally involved. When both temporal lobes are affected, the finding is practically pathognomonic. In AIDS, herpes infection of other portions of the brain has been reported. 1,7

\section{Neoplasma}

Lymphoma is most common, whereas Kaposi's sarcoma is very rare.

\section{Lymphoma}

Both primary and secondary lymphoma occur in the CNS, the former much more frequently than the latter. ${ }^{1}$ Primary lymphoma used to be very rare in the CNS, but its incidence has tripled due to its frequent occurrence in AIDS. Almost all are of the non-Hodgkin variety. In contradistrinction to secondary lymphoma which is usually extra-axial (subarachnoidal; extradural), primary lymphoma is most commonly parenchymal (intracerebral). Primary lymphoma is the number two cause of an intracranial mass in AIDS, it usually enhances in a ring-like pattern, and may be multiple in up to $50 \%$ of cases. Thus, differentiation from toxoplasma encephalitis can be difficult. On the other hand, when a single lesion is found on MRI, it is four times more likely to be lymphoma than toxoplasmosis. ${ }^{11}$ The preceding is also in stark contrast to primary lymphoma in non-AIDS patient, in which the lesion is hardly ever multiple, and where the enhancement is often homogenous and intense. ${ }^{1,11}$ Parenchymal lymphoma is classically found in the deep gray matter, periventricular area and the corpus callosum. Up to three quaters of these masses extend to the ependymal lining of the ventricles, the meninges, or both. The masses do not calcify and hematoma formation is rare. The lesions are often is so intense to gray matter on all spin-echo sequences, a finding often encountered with small cell, hypercellular tumors.

\section{HIV related}

Very common: ADC. Rare: vacuolar myelopathy (the thoracic spinal cord is most severely affected), and aseptic meningitis (sometimes with facial nerve involvement; usually self limited, but may recur).

\section{$A D C$}

Direct infection of the brain by HIV causes subacute encephalitis, and the presence of multinucleated giant cells, scattered or clustered in microglial nodules, first in the white matter, and later in the basal ganglia and cerebral cortex. They are also found in the brainstem, cerebellum and spinal cord. Although MRI is better than CT, magnetic imaging will detect abnormalities at a relatively late stage of the disease, ${ }^{12}$ most commonly in the form of enlargement of the sulci and ventricles (atrophy), and small patchy hyperintensities which may progress, enlarge, and become confluent. The hyperintense lesions represent areas of demyelination and vacuolization. Cerebral atrophy itself is very common in AIDS, occuring in $40 \%$ of cases, and can also be seen in other brain infections such as toxoplasmosis and CMV. Subacute HIV encephalitis in the AIDS patient who clinically has dementia, is called the AIDS dementia complex, or ADC. On MRI, widespread, diffuse involvement of a large area correlates well with ADC. Patchy or punctate lesions can also be found in ADC, but are less common. ${ }^{13}$ The lesions do not enhance, and tend to be more symmetrical than in PML. ${ }^{1,7}$

\section{CVA}

Cerebrovascular occlusive disease, intracranial hemorrhage and vasculitis have been reported in AIDS patients, usually in conjunction with opportunistic infections or neoplasms. ${ }^{1,7}$ 

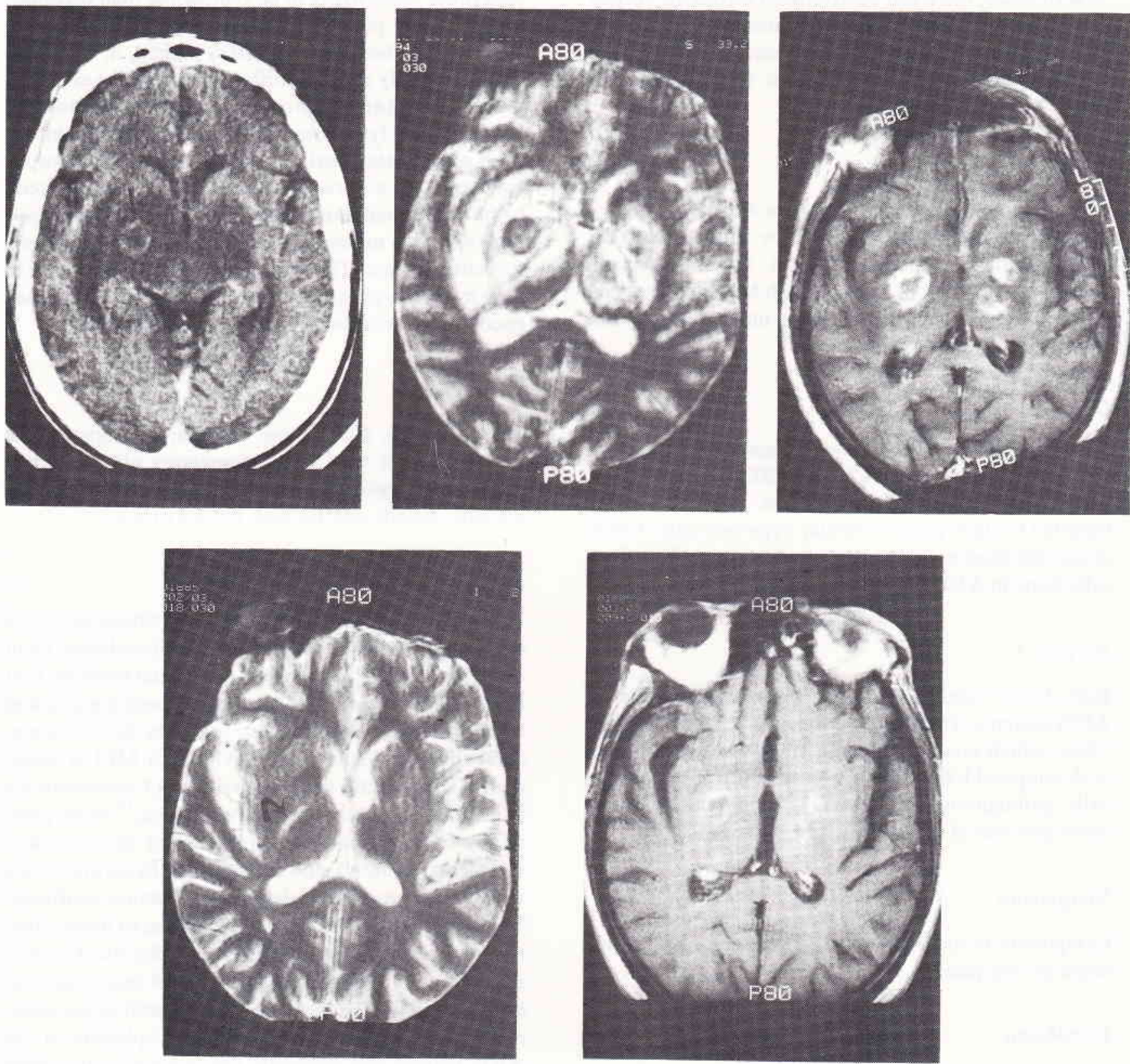

Figure 1.Contrast-augmented CT (a) shows bilateral thalamic and basal ganglia swelling. A ring-enhancing lesion is present on the right (arrow). Despite motion artifacts caused by the restless patient, the lesions are better depicted by MRI, especially on the left side $(b, c)$. Two weeks later following therapy with pyrimethamine and sulfadiazine, the lesions have regressed markedly; leaving just a small hyperintensity (curved arrow; d), and less marked enhancement (e). (b,d: T2W TRTE 3500/90, and c, e: post-contrast TIW 750/20). 


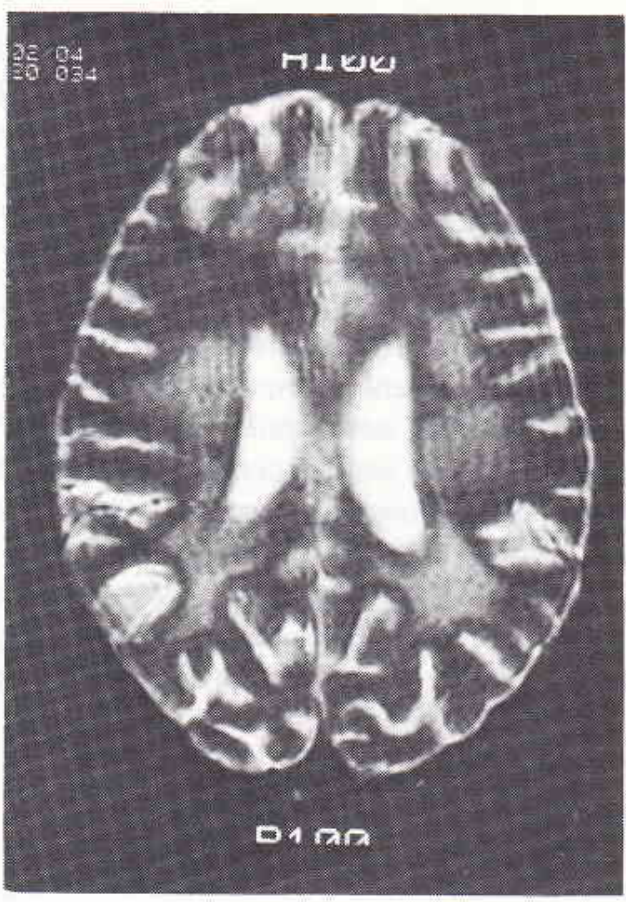

Figure 2. This 30-year-old HIV + male developed large, bilateral white matter hyperintense lesions, as seen on the T2W 3500/90 image. He was clinically believed to have developed PML, but histopathological confirmation could not be obtained. The hyperintense lesions in PML tend to be more asymmetrical than in the AIDS dementia complex $(A D C)$, they may involve the gray matter, and enhancement can occur.

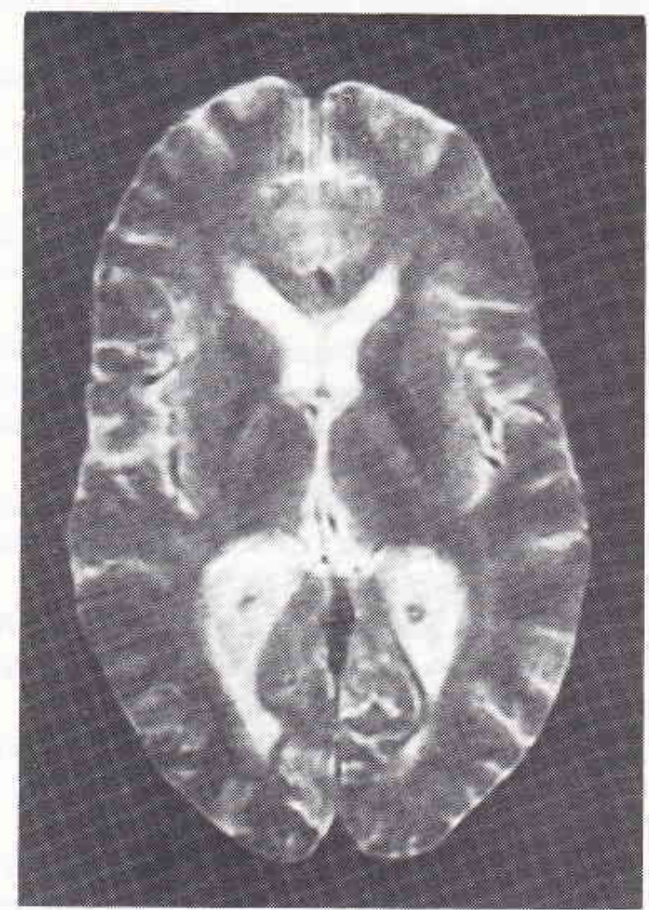

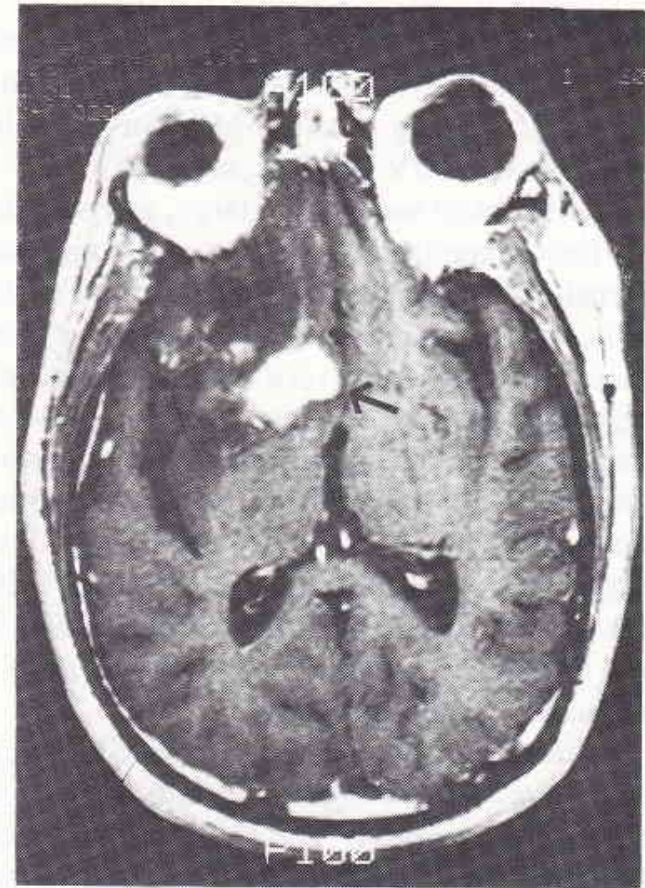

Figure 3. A large, irregular mass with an enhancing center (arrow) is present in the right basal ganglialfrontal lobe area. Since there was no other lesion, the pre-operative diagnosis favored lymphoma, rather than toxoplasmosis. This was histologically confirmed (MRI, post-contrast T1W 500/20).

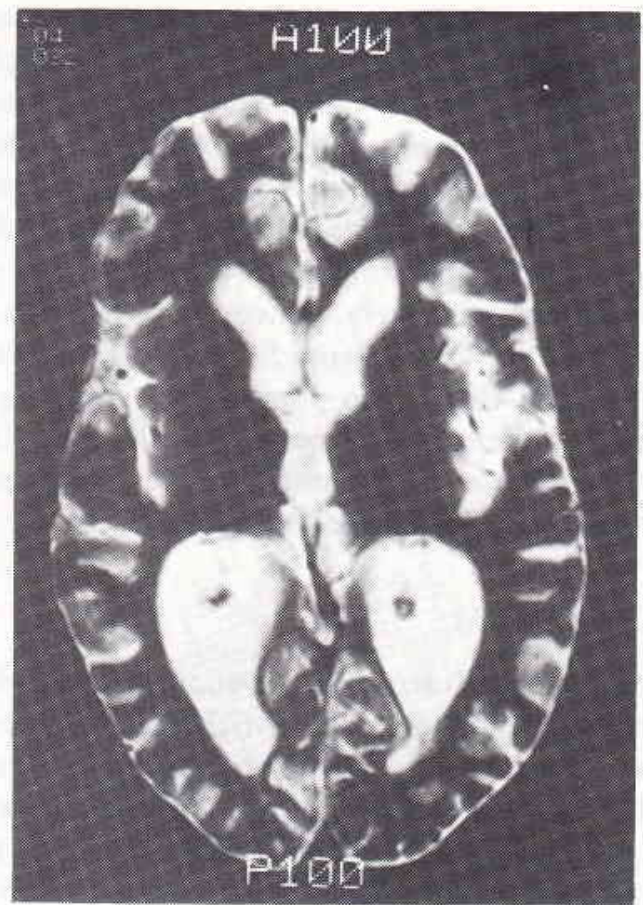

Figure 4. This 25-year-old HIV + male had an essentially normal MR scan upon presentation (a: T2W 2000/80). A repeat study 2 years later ( $b: T 2 W$ 3500/90) demonstrated significant sulcal widening and ventricular dilatation, indicating atrophy, a common finding in: subacute HIV encephalitis. 
In the earlier stages of the disease the yield of CT and MRI is low. It is pointless, for example, to perform routine screening cranial MRI in neurologically asymptomatic HIV-positive subjects. ${ }^{14} \mathrm{CT}$ will undoubtedly detect most of the large, and obvious abnormalities, especially if done with enhancement. Extensive areas of brain involvement by toxoplasmosis or lymphoma, for example, are not likely to be missed. Moderate to severe atrophy is also commonly diagnosed, or at least suspected, on CT. However, it is clear that in most instances MRI is superior to CT. Enhanced MRI is often very helpful in revealing the extent, or the number of lesions, however T2 weighted images can actually be superior. ${ }^{15}$ When MRI is performed, it is best to perform short and long TR spinecho sequences, as well as a series of post- contrast enhanced $\mathrm{T} 1$ weighted images.

A number of nuclear medicine (SPECT, or single proton emission computed tomography), positron emission tomography (PET) and MR spectroscopy studies have shown promise in showing early manifestations of the disease, sometimes in the absence of CT or MRI abnormalities. They can also used to document improvement, as the patient improves clinically. $1,7,16$

\section{CONCLUSION}

The relentless increase in HIV-positive and AIDS patients will almost certainly cause an increase in positive imaging studies of the CNS. Toxoplasmosis and lymphoma are the most common cause of intracranial masses in AIDS, and they share many of the imaging characteristics. Clinical management often includes an empirical trial of antitoxoplasmosis medications. It is important to definitively diagnose toxoplasmosis early, since the infection usually responds well to therapy. Subacute HIV encephalitis, $\mathrm{ADC}$ and PML also share some imaging characteristics, their clinical course is relentless. Other entities which are uncommon, or are rarely manifested on imaging studies, are briefly discussed.

\section{ADDENDUM}

Spin-echo (SE) sequences are commonly used in magnetic resonance imaging (MRI). T1 weighted (T1W) and $\mathrm{T} 2 \mathrm{~W}$ sequences are integral components of SE MRI. The T1W sequence is characterized by a short repetition time (TR), and a short echo time (TE), for example TR/TE 750/20. Both the TR and the TE values are expressed in milliseconds. Long TR and long TE values signify the $\mathrm{T} 2 \mathrm{~W}$ sequence, for example $3500 / 90$. Because of these characteristics, many normal and pathologic findings show different signal in- tensities on T1W and T2W MRI. Edema, for example, shows up as a hyperintense ("bright") area on T2W images, but is hypointense ("dark") on T1W images. The intravenously administered MRI contrast material used was gadopentetate dimeglumine (Gd-DTPA) which shortens both $\mathrm{T} 1$ and $\mathrm{T} 2$, thereby resulting in areas of greater or lesser signal intensity, respectively. Post-contrast MR imaging is customarily done with T1W sequences, where enhancement is seen as hyperintense signal. As with computed tomography (CT), enhancement within the central nervous system is due to either vascular structures, or disruption of the bloodbrain barrier which then allows contrast material to escape into the brain parenchyma. Contrast-enhanced MRI is more sensitive then contrast-enhanced CT, in that it allows detection of more lesions, or more extensive pathology, or both.

\section{REFERENCES}

1. Reeders JWAJ. Diagnostic imaging in AIDS. Stuttgart: Georg Thieme Verlag, 1992.

2. Hollander H, Katz MH. HIV-related conditions. In: Schroeder SA, Tiemey LM, McPhee SJ, Papadakis MA, Krupp MA, editors. Current medical diagnosis \& treatment. Norwalk: Appleton \& Lange, 1992; 992-1008.

3. AIDS sejagad. Berita Epidemiol RI, Juli 1992.

4. Ilyas J. Masalah dan kebijaksanaan pencegahan dan pemberantasan acquired immuno deficiency syndrome (AIDS) di Indonesia. Berita Epidemiol RI, 1992; 7-15.

5. Ridwan RM. Pengidap HIV dan kasus AIDS di Indonesia s.d. 30 Juni 1993; 18-22.

6. Utomo B. Masalah dan implikasi epidemiologi AIDS di Indonesia. Bul Epidemiol Indon 1992; 4: 1-35.

7. Bowen BC, Donovan Post MJ. Intracranial infection. In: Atlas SW. Magnetic resonance imaging of the brain and spine. New York: Raven Press, 1991; 501-38.

8. Wheeler AL, Truwit CL, Kleinschmidt-DeMasters BK, Byrne WR, Hannon RN. Progressive multifocal leukoencephalopathy: contract enhancement on CT scans and MR images. Am J Roentgenol 1993; 161: 1049-51.

9. Mark AS, Atlas SW. Progressive multifocal leukoencephalopathy in patients with AIDS: appearance on MR images. Radiology 1989; 173: 517-20.

10. Mathews VP, Alo PL, Glass JD, Kumar AJ, McArthur JC. AIDS-related CNS cryptococcosis: radiologic-pathologic correlation. AJNR 1992; 13: 1477-86.

11. Rauch RA, Bazan C III, Jinkins RJ. Imaging of infections of the central nervous system. Curr Opinion Radiol 1992; 4: 43- 51 .

12. Donovan Post MJ, Tate LG, Quencer RM, Hensley GT, Berger JR, Sheremata WA, Maul G. CT, MR, and pathology in HIV encephalitis and meningitis. AJNR 1988; 9: 469-76.

13. Olsen WL, Longo FM, Mills CM, Norman D. White matter disease in AIDSL: findings at MR imaging. Radiology 1988; 169: 445-8. 
14. Donovan Post MJ, Berger JR, Duncan R, Quencer RM, Pall L, Winfield D. Asymptomatic and neurologically symptomatic HIV- seropositive subjects: results of longterm MR imaging and clinical follow-up. Radiology 1993; 188: 727-33.
15. Brant-Zawadski M, Mattox S. Value of Gd-DTPA in brain MRI of Aids patients. MRI Decisions 1991; Jul/Aug: 2-10.

16. Donovan Post MJ. Neuroimaging in various stages of human immunodeficiency virus infection. Cur Opin Radiol 1990; 2: 73-9. 